\title{
Modern Elektrikli, Hibrit Elektrikli ve Yakıt Hücreli Taşıtlar
}

Üçüncü Baskıdan Çeviri

\author{
Yazarlar \\ Mehrdad EHSANI \\ Yimin GAO \\ Stefano LONGO \\ Kambiz M. EBRAHIMI
}

Çeviri Editörü

Mustafa AKTAŞ 


\title{
(C) Copyright 2021
}

Bu kitabın, basım, yayın ve satış hakları Akademisyen Kitabevi A.Ş.'ne aittir. Anılan kuruluşun izni alınmadan kitabın tümü ya da Bölümleri mekanik, elektronik, fotokopi, manyetik kağıt ve/veya başka yöntemlerle çoğaltılamaz, basılamaz, dağıtılamaz. Tablo, şekil ve grafikler izin alınmadan, ticari amaçh kullanılamaz. Bu kitap T.C. Kültür Bakanhı̆ı bandrolü ile satilmaktadir.

$\begin{array}{rl}\text { Orijinal ISBN } & \text { ISBN } \\ 978-1-4987-6177-2 & 978-625-7451-94-9\end{array}$

Orijinal Adı Yayın Koordinatörü

Modern Electric, Hybrid Electric, and Yasin DİLMEN

Fuel Cell Vehicles

$\begin{aligned} \text { Yazarlar } & \text { Akademisyen Dizgi Ünitesi } \\ \text { Mehrdad EHSANI } & \\ \text { Yimin GAO } & \text { Yayıncı Sertifika No } \\ \text { Stefano LONGO } & 47518\end{aligned}$

Kambiz M. EBRAHIMI

Modern Elektrikli, Hibrit Elektrikli ve

$$
\text { Kitap Adı Vadi Matbaacilıkt }
$$

Yakıt Hücreli Taşıtlar Bisac Code

TEC009090

Çeviri Editörleri

Mustafa AKTAŞ DOI

ORCID iD: 0000-0002-2608-1000 10.37609/akya.825

\author{
GENEL DAĞITIM \\ Akademisyen Kitabevi A.Ş. \\ Halk Sokak 5 / A \\ Yenişehir / Ankara \\ Tel: o312 4311633 \\ siparis@akademisyen.com
}

www . akademisyen.com 
To my Wonderful Wife, Zohreh

Mehrdad EHSANI

To my Wife Anni, and my Daughter, Yuan

Yimin GAO

To my Mum, Dad and Little Brother

Stefano LONGO

To my Wife and Daughter

Kambiz EBRAHIMI 



\section{İçindekiler}

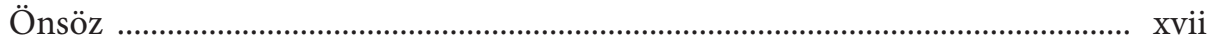

Çeviri Önsözü ............................................................................................. xxiii

Mehrdad Ehsani'nin tercüme kitap hakkında yazısı ………………………….. xxiv

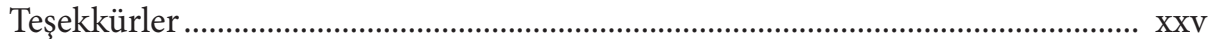

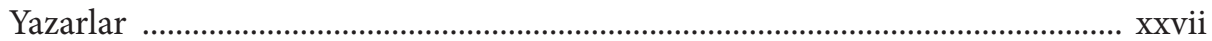

1. Modern Taşımacılığın Çevreye Etkisi ve Tarihi .................................................. 1

Çeviri: Prof. Dr. Mustafa AKTAŞ

1.1. Hava Kirliliği .....................................................................................................

1.1.1. Nitrojen Oksitler .................................................................................2

1.1.2 Karbon Monoksit ...............................................................................

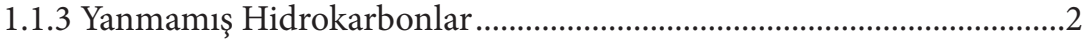

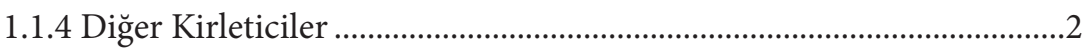

1.2 Küresel Isınma...............................................................................................

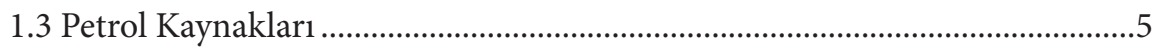

1.4 Maliyetler ..................................................................................................

1.5 Farklı Taşımacılık Geliştirme Planlarının Gelecekte Petrol

Kaynaklarına Etkisi .....................................................................................

1.6 Elektrikli Taşıtların Tarihi ............................................................................... 11

1.7 HET'lerin Tarihi ....................................................................................... 12

1.8 Yakıt Hücreli Taşıtların Tarihi ......................................................................... 14

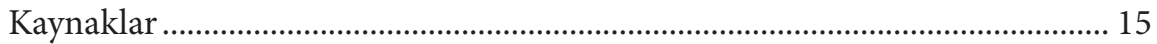

2. Taşıtlarda Tahrik ve Frenlemenin Temel İlkeleri............................................17 Çeviri: Doç. Dr. Mesut DÜZGÜN

2.1 Taşıt Hareketinin Genel Tanımları...................................................................... 17

2.2. Taşıt Direnci ………………………………………………………………..... 17

2.2.1. Yuvarlanma Direnci......................................................................... 18

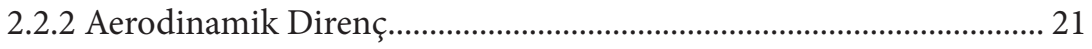

2.2.3 Eğim Direnci …………………………………………………..... 21

2.3 Hareket Denklemi ......................................................................................... 23

2.4 Tekerlek-Zemin Tutunması ve Azami Tahrik Kuvveti ................................. 25

2.5 Güç Aktarma Sistemi Tahrik Kuvveti ve Taşıt Hızı......................................... 27

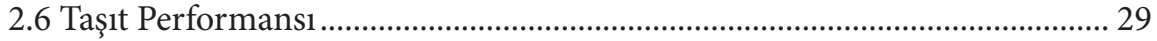

2.6.1 Taşıııı Azami Hızı ............................................................................. 30

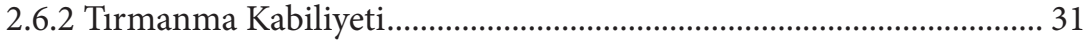

2.6.3 İvmelenme Performans1..................................................................... 31 


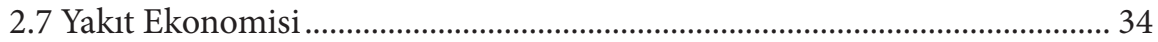

2.7.1 İçten Yanmalı Motorların Yakıt Ekonomisi Özellikleri ........................ 34

2.7.2 Taşıt Yakıt Ekonomisinin Hesaplaması................................................... 35

2.7.3 Taşıtın Yakıt Ekonomisini Geliştirmek için Basit Teknikler .............. 37

2.8 Fren Performans1 ........................................................................................ 38

2.8.1 Frenleme Kuvveti .............................................................................. 39

2.8.2 Ön ve Arka Akslarda Fren Kuvvet Dağılımı ....................................... 41

2.8.3 Frenleme Düzenlemesi ve Frenleme Performans Analizi ................... 45

2.8.3.1 Frenleme Düzenlemesi ............................................................ 45

2.8.3.2 Frenleme Performans Analizi ..................................................... 47

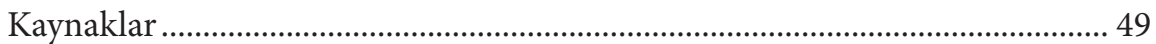

3. İçten Yanmalı Motorlar..................................................................................51

Çeviri: Prof. Dr. Can ÇINAR

3.1 Buji ile Ateşlemeli Motorlar............................................................................. 51

3.1.1 Temel Yapısı, Otto Çevrimi ve Çalışma Prensibi.................................. 51

3.1.2 Çalışma Parametreleri ................................................................................ 53

3.1.2.1. Nominal Değerler................................................................... 53

3.1.2.2 İndike Tork ve İndike Ortalama Efektif Basınç....................... 53

3.1.2.3 Fren Ortalama Efektif Basınç (bmep) ve Fren Torku ............. 56

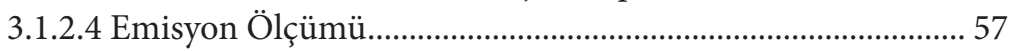

3.1.2.5 İçten Yanmalı Motor Çalışma Karakteristikleri ....................... 58

3.1.3 İçten Yanmalı Motor Performansı, Verim ve Emisyonları İyileştirmek İçin Kullanılan Temel Yöntemler ........................................................... 59

3.1.3.1 Aşırı Doldurma.......................................................................... 59

3.1.3.2 Doğrudan Benzin Enjeksiyonu ve Fakir Yanmalı Motorlar . 61

3.1.3.3 Çoklu Supap ve Değişken Supap Zamanlamas1 ...................... 61

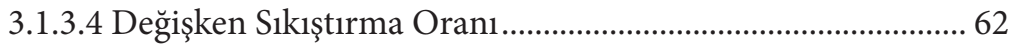

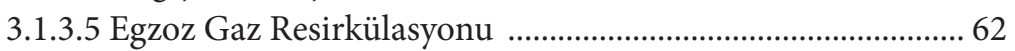

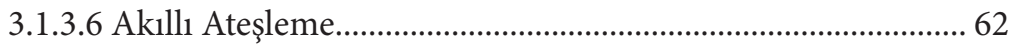

3.1.3.7. Yeni İçten Yanmalı Motor Malzemeleri.................................. 62

3.1.4 Buji ile Ateşlemeli Motor Kontrol Sistemine Bakış ................................. 62

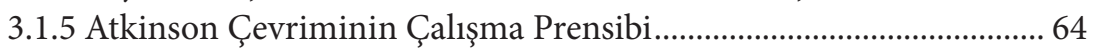

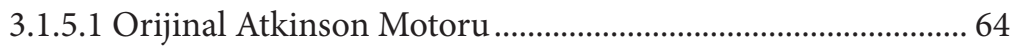

3.1.5.2 Modern Atkinson Motoru ......................................................... 65

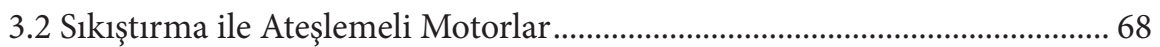

3.3 Alternatif Yakıtlar ve Motorlarda Alternatif Yakıt Kullanımı ........................ 69

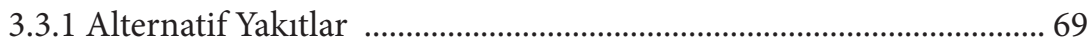

3.3.1.1. Etanol ve İçten Yanmalı Motorlarda Etanol Kullanımı ........ 69

3.3.1.2 Sıkıştırılmış Doğalgaz ve Doğalgazlı Motorlar ........................ 71

3.3.1.3 Geliştirilmiş Hidrojen $\left(\mathrm{H}_{2}\right)$ Yanmas1 ........................................ 72

Kaynaklar .................................................................................................... 72 
4. Taşıt Güç Aktarma Sistemi .73 Çeviri: Doç. Dr. Tolga TOPGÜL

4.1 Güç Sisteminin Özellikleri ................................................................................ 73

4.2 Güç Aktarmanın Özellikleri............................................................................ 76

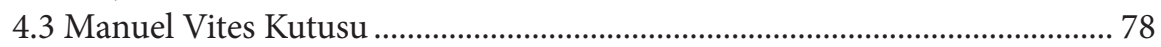

4.4 Otomatik Vites Kutusu..................................................................................... 81

4.4.1 Geleneksel Otomatik Vites Kutusu................................................... 82

4.4.1.1 Tork Konvertörünün Çalışması.................................................. 82

4.4.1.2 Planet veya Episiklik Dişli Sistemi ............................................ 86

4.4.1.3 Birleşik Episiklik Dişli................................................................... 88

4.4.2 Otomatikleştirilmiş Manuel ve Çift Kavramalı Vites Kutusu ............ 89

4.5 Sürekli Değişken Vites Kutusu........................................................................ 91

4.6 Sonsuz Değişken Vites Kutusu..................................................................... 91

4.7 Özel Hibrit Güç Aktarma Sistemleri............................................................... 92

Kaynaklar .................................................................................................. 93

5. Elektrikli Taşıtlar...............................................................................................95

Çeviri: Prof. Dr. Mustafa AKTAŞ

5.1 Elektrikli Taşıtların Özellikleri............................................................................ 95

5.2 Elektrikli Taşıtların Performansı ..................................................................... 98

5.2.1 Tahrik Motoru Özellikleri.................................................................. 98

5.2.2 Tahrik Kuvveti ve Aktarım İhtiyac1 .................................................... 99

5.2.3 Taşıిt Performans1 ............................................................................... 101

5.3 Normal Sürüşte Tahrik Gücü.......................................................................... 103

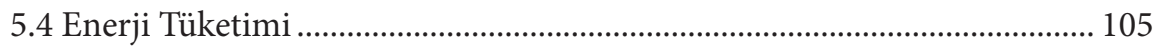

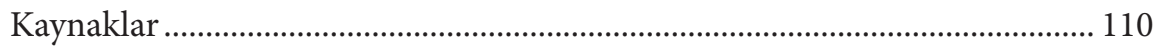

6. Hibrit Elektrikli Taşıtlar........................................................................113

Çeviri: Prof. Dr. Necmi ALTIN

6.1 Hibrit Elektrikli Aktarma Elemanı Kavramı................................................. 113

6.2 Hibrit Elektrikli Aktarma Sistemi Mimarileri ............................................... 116

6.2.1 Seri Hibrit Elektrikli Aktarma Sistemi (Elektrikli bağlantı) ........... 117

6.2.2 Paralel Hibrit Elektrikli Aktarma Sistemi (Mekanik bağlantı) ....... 119

6.2.2.1 Moment Birleştirici ile Paralel Hibrit Aktarma Sistemi ............... 120

6.2.2.1.1 Moment Birleştirici Cihazlar.............................................. 120

6.2.2.1.2 Moment Birleştirici ile Aktarma Sistemi Özellikleri...... 121

6.2.2.2 Hız Birleştirici ile Paralel Hibrit Aktarma Sistemi ............. 126

6.2.2.2.1 Hız Birleştirici Elemanlar1 .................................................. 126

6.2.2.2.2 Hız Birleştirici ile Aktarma Sistemi Yapıs1....................... 129

6.2.2.3 Moment ve Hız Birleştirici ile Hibrit Aktarma Sistemi .... 132

6.2.2.3.1 İsteğe Bağlı Birleștirici Seçilebilen Çalışma Modu .......... 132

6.2.2.3.2 Her iki Birleştirici ile Çalışma Modu.................................... 133

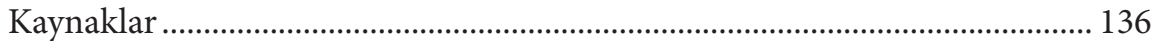


7. Elektrikli Tahrik Sistemleri

Çeviri: Dr. Öğr. Üyesi Tayfun GÜNDOĞDU

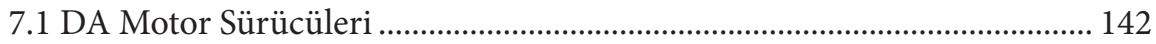

7.1.1 Çalışma Prensibi ve Performans1 ........................................................ 142

7.1.2 Birleşik Armatür Gerilimi ve Alan Kontrolü ....................................... 145

7.1.3 DA Motorlarının Kıyıcı ile Kontrolü..................................................... 145

7.1.4 Kıyıcı Beslemeli DA Motor Sürücülerinin Çok-Bölgeli Kontrolü . 150

7.1.4.1 İleri Sürüş ve Rejeneratif (Geri-kazanıml)

Frenlemenin İki Bölgeli Kontrolü ........................................ 150

7.1.4.1.1 Ters Anahtarlı Tek Kiyıc1....................................................... 150

7.1.4.1.2 C Sınıfı İki Bölge Kıyıc1 ....................................................... 151

7.1.4.2 Dört Bölgede Çalışma............................................................... 152

7.2 Asenkron Motor Sürücüleri ........................................................................ 153

7.2.1 Asenkron Motorların Temel Çalışma İlkeleri .................................... 154

7.2.2 Kararlı Durum Performans1 ............................................................ 157

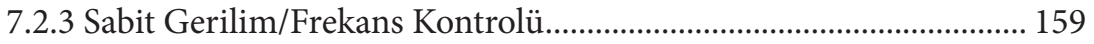

7.2.4 Güç Elektroniği Kontrolü .................................................................. 160

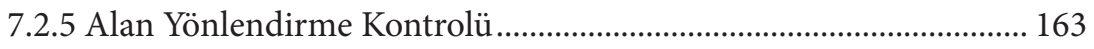

7.2.5.1 Alan Yönlendirme İlkeleri.................................................... 163

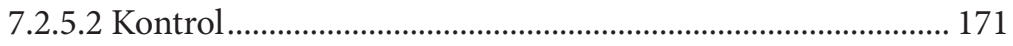

7.2.5.3 Doğrudan Rotor Akı Yönlendirme Şeması............................ 172

7.2.5.4 Dolaylı Rotor Akı Yönlendirme Şeması ................................. 175

7.2.6. Alan Yönlendirme Kontrolü için Gerilim Kaynaklı İnverter .......... 177

7.2.6.1. Gerilim Kaynaklı İnverterde Gerilim Kontrolü ................... 179

7.2.6.2 Gerilim Kaynaklı İnverterde Akım Kontrolü......................... 181

7.3 Kalıcı Mıknatıslı FDAM (Fırçasız Doğru Akım Motor)

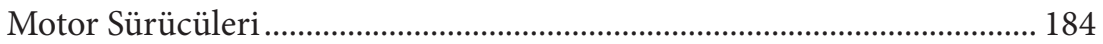

7.3.1 FDAM Motor Sürücülerinin Temel Prensipleri................................. 185

7.3.2 FDAM Makine Yapısı ve Sinıflandırması ........................................... 185

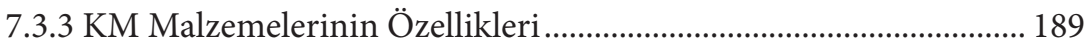

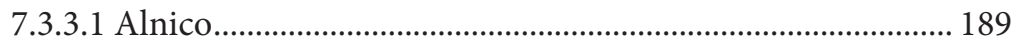

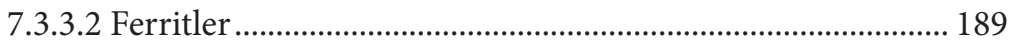

7.3.3.3 Nadir Toprak Miknatısları ....................................................... 190

7.3.4 FDAM Makinelerinin Performans Analizi ve Kontrolü................... 190

7.3.4.1 Performans İnceleme .............................................................. 190

7.3.4.2 FDAM Motor Sürücülerinin Kontrolü.................................. 193

7.3.5 Hız Arttırma Teknolojisi.................................................................. 194

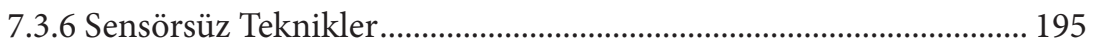

7.3.6.1 Ölçümleri ve Matematiği Kullanan Yöntemler ...................... 195

7.3.6.2 Gözlemci Kullanan Yöntemler................................................ 196

7.3.6.3 Ztt EMK Algılamayı Kullanan Yöntemler.............................. 196

7.3.6.4 Özel Sensörsüz Teknikler ........................................................ 197 
7.4 Anahtarlamalı Relüktans Motor (ARM) Sürücüleri ................................. 198

7.4.1 Temel Manyetik Yap1 ....................................................................... 198

7.4.2 Moment Üretimi ................................................................................ 201

7.4.3 ARM Sürü cü................................................................................... 204

7.4.4 Çalışma Modları................................................................................. 206

7.4.5 Generatör Modu Çalışma (Rejeneratif/Geri-Kazanımlı

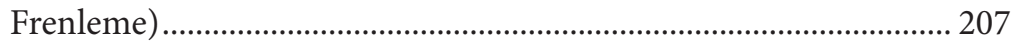

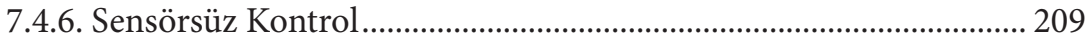

7.4.6.1 Faz Akı Bağlantısına Dayalı Yöntem.................................... 210

7.4.6.2 Faz Endüktansına Dayalı Yöntem ......................................... 211

7.4.6.2.1 Faz Toplu Endüktansına Dayalı Sensörsüz Kontrol ......... 211

7.4.6.2.2 Faz Artımlı Endüktansa Dayalı Sensörsüz Kontrol .......... 212

7.4.6.3 Modüle sinyal ilave edilen yöntemler ................................... 212

7.4.6.3.1 Frekans Modülasyon Yöntemi ............................................ 213

7.4.6.3.2 Genlik Modulasyon ve Faz Modülasyon

(GM ve FM) Yöntemleri .................................................. 213

7.4.6.3.2 Darbe Tabanlı Teşhis Yöntemi............................................. 213

7.4.6.4 Ortak Endüklenen Gerilim Tabanlı Yöntem ........................ 214

7.4.6.5 Gözlemciye Dayalı Yöntemler .............................................. 214

7.4.7 ARM Sürücülerinin Kendiliğinden-Ayar Teknikleri ....................... 215

7.4.7.1 Aritmetik Yöntemle Kendiliğinden Ayar .............................. 215

7.4.7.1.1 Dengeli Endüktans Değerleri ile Optimizasyon................ 216

7.4.7.1.2 Parametre Değişimleri Durumunda Optimizasyon......... 216

7.4.7.2 Yapay Sinir A $\breve{g}_{1}$ (YSA) Kullanarak

Kendiliğinden Ayarlama....................................................... 216

7.4.8 ARM'de Titreşim ve Ses Gürültüsü................................................... 218

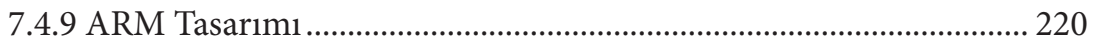

7.4.9.1 Stator ve Rotor Kutup Sayıs1 ................................................ 220

7.4.9.2 Stator Diş Çapı ............................................................................ 221

7.4.9.3 Rotor Diş Çap1 .......................................................................... 221

7.4.9.4 Hava Aralığ1 ...................................................................... 222

7.4.9.5 Stator Boyunduruğunun İç Kavisi........................................ 222

7.4.9.6 Stator Boyunduruğu............................................................ 222

7.4.9.7 Performans Tahmini .......................................................... 222

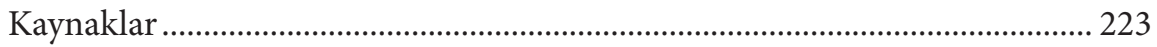

8. Seri (Elektrik Bağlantılı) Hibrit Elektrikli Aktarma Sistemi ...................229

Çeviri: Prof. Dr. Necmi ALTIN

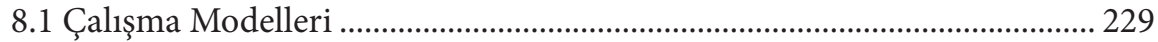

8.2 Kontrol Yöntemleri ..................................................................................... 231

8.2.1 Azami PPS SOC'si Kontrol Yöntemi ................................................ 232

8.2.2 Motor Açma-Kapatma veya Termostat Kontrol Yöntemi ............... 233 
8.3 Seri (Elektrik Bağlantılı) Hibrit Aktarma Sisteminin Tasarım İlkeleri..... 234

8.3.1 Elektrikli Birleştirme Cihazı............................................................. 234

8.3.2 Tahrik Motorunun Güç Değeri Tasarımı ......................................... 238

8.3.3 İYM/Generatörün Güç Değeri Tasarımı ......................................... 241

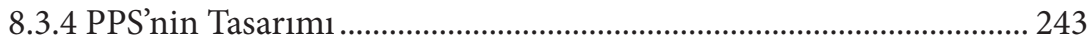

8.3.4.1 PPS’nin Güç Kapasitesi ........................................................... 245

8.3.4.2 PPS’nin Enerji Kapasitesi ................................................... 245

8.4 Tasarım Örneği ........................................................................................ 246

8.4.1 Tahrik Motoru Boyutunun Tasarımı................................................ 246

8.4.2 Dişli Oranının Tasarımı ................................................................... 246

8.4.3 Hizlanma Performansının Doğrulanması ...................................... 247

8.4.4 Tirmanma Kabiliyetinin Doğrulanması ........................................ 247

8.4.5 IYYM/Generatör Boyutu Tasarımı ................................................... 247

8.4.6 PPS’nin Güç Kapasitesi Tasarımı ..................................................... 249

8.4.7 PPS’nin Enerji Kapasitesi Tasarımı.................................................... 250

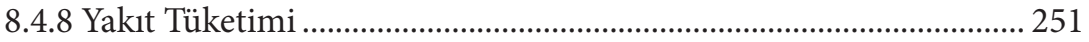

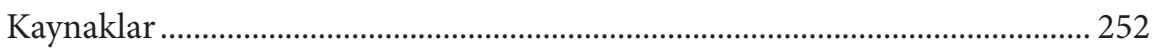

9. Paralel (Mekanik Olarak Bağlı) Hibrit Elektrik Güiç

Aktarma Sistemi Tasarımı .................................................................... 255

Çeviri: Doç. Dr. Fatih ŞAHİN

9.1 Güç Aktarım Sistemi Yapısı ve Tasarım Hedefleri ..................................... 255

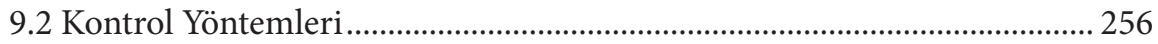

9.2.1 PPS Azami Şarj Durumu Kontrol Yöntemi ...................................... 257

9.2.2 İçten Yanmalı Motor Aç-Kapa (Termostat) Kontrolü....................... 260

9.2.3 İçten Yanmalı Motor Kısıtlı Aç-Kapa Kontrol Yöntemi.................... 261

9.2.4 Bulanık Mantık Kontrol Tekniği .................................................... 263

9.2.5 Dinamik Programlama Tekniği ...................................................... 264

9.3 Güç Aktarma Sisteminin Parametre Tasarımı .......................................... 267

9.3.1 İçten Yanmalı Motor Gücü ................................................................ 267

9.3.2 Aktarım Elemanı Tasarımı ............................................................... 270

9.3.3 Elektrik Motoru Tahrik Gücü ....................................................... 271

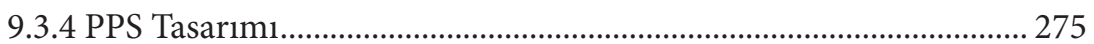

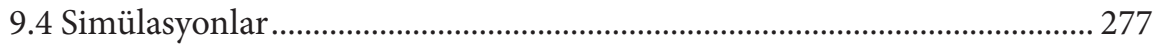

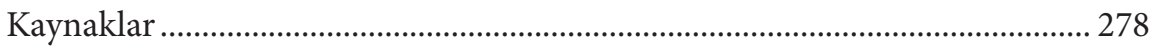

10. Seri-Paralel (Moment ve Hız Birleştirme) Hibrit Güç Aktarma

Sistemi Tasarımı ve Kontrolï ................................................................ 281

Çeviri: Prof. Dr. Ahmet Faruk BAKAN

10.1 Güç Aktarma Sistemi Yapısı .................................................................. 281

10.1.1 Hiz-Birleştirme Analizi................................................................ 281

10.1.2 Güç Aktarma Sistemi Özellikleri.................................................. 283 
10.2 Güç Aktarma Sistemi Kontrol Yöntemi................................................. 291

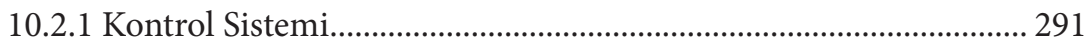

10.2.2 İYM Hız Kontrol Yaklaşımı.............................................................. 291

10.2.3. Tahrik Momenti Kontrolü .............................................................. 292

10.2.4. Güç Aktarma Sistemi Kontrol Yöntemleri .................................... 293

10.2.4.1. İYM Hiz Kontrol Yöntemi.................................................. 294

10.2.4.2 Tahrik Momenti Kontrol Yöntemi ..................................... 296

10.2.4.2.1. Düşük Hız Bölgesi............................................................. 296

10.2.4.2.2. Orta Hiz Bölgesi ........................................................... 297

10.2.4.2.3. Yüksek Hiz Bölgesi........................................................ 297

10.2.4.3. Geri Kazanımlı (Rejeneratif) Frenleme Kontrolü............. 298

10.3. Güç Aktarma Sistemi Parametre Tasarımı.............................................. 298

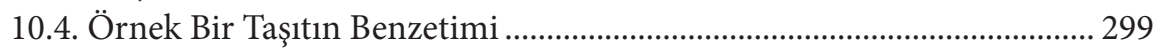

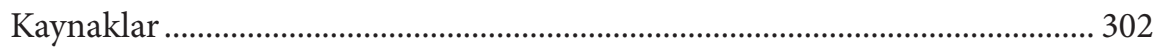

\section{Fişli (Şebekeden Şarjlı) Hibrit Elektrikli Taşıtların}

Tasarım ve Kontrol İlkeleri.........................................................................305

Çeviri: Prof. Dr. Ahmet Faruk BAKAN

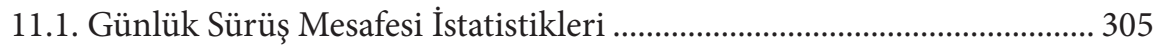

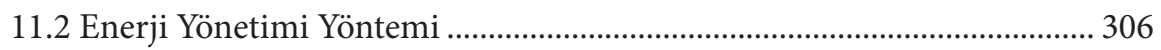

11.2.1. AER Merkezli Kontrol Yöntemi ...................................................... 307

11.2.2. Karma Kontrol Yöntemi............................................................. 312

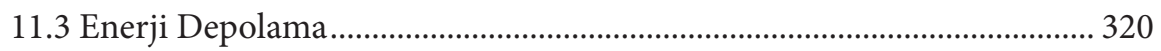

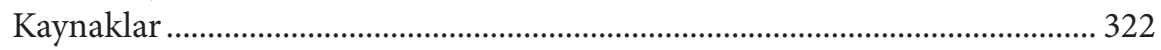

12. Hafif Hibrit Elektrikli Aktarma Sistemi Tasarımı .................................. 323

Çeviri: Prof. Dr. Necmi ALTIN

12.1 Frenleme ve Güç Aktarımında Harcanan Enerji...................................... 323

12.2 Paralel Hafif Hibrit Elektrikli Aktarma Sistemi........................................ 325

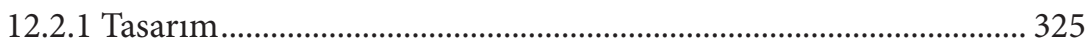

12.2.2 Çalışma Durumları ve Kontrol Yöntemi ........................................ 325

12.2.3 Aktarma Sistemi Tasarımı ............................................................... 326

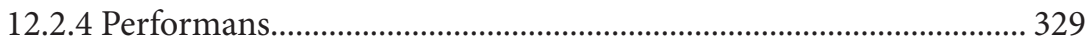

12.3 Seri-Paralel Hafif Hibrit Elektrikli Aktarma Sistemi ................................ 331

12.3.1 Planet Dişli ile Aktarma Sistemi Tasarımı..................................... 331

12.3.2 Çalışma Durumları ve Kontrol ....................................................... 336

12.3.2.1 Hız Birleştirici Çalışma Durumu ......................................... 336

12.3.2.2 Moment Birleştirici Çalışma Durumu ................................. 337

12.3.2.3 Yalnı IYM Tahrik Modu .................................................. 338

12.3.2.4 Yalnız Motor Tahrik Modu ................................................. 338

12.3.2.5 Geri Kazanımlı Frenleme Modu ........................................ 339

12.3.2.6 İYM’nin Çalıştırılması ........................................................... 339 


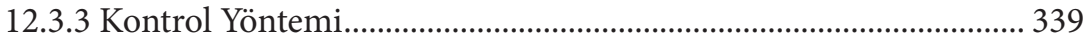

12.3.4 Statoru Dönen Motor ile Aktarma Sistemi....................................... 340

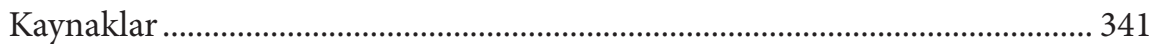

13. Anlık Güç Kaynakları ve Enerji Depolama ...................................................343

Çeviri: Prof. Dr. Okan ÖZGÖNENEL

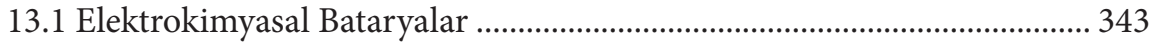

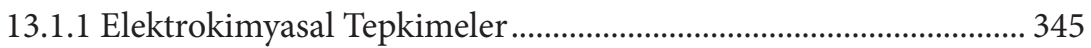

13.1.2 Termodinamik Gerilim.................................................................... 346

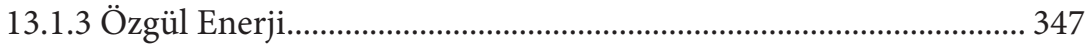

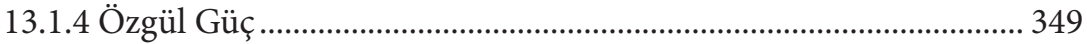

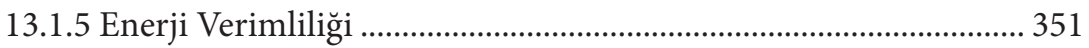

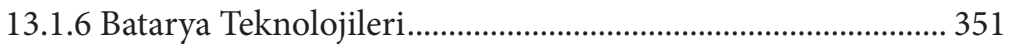

13.1.6.1 Kurşun-Asit Batarya .............................................................. 352

13.1.6.2 Nikel Temelli Bataryalar....................................................... 353

13.1.6.2.1 Nikel-Demir Batarya ......................................................... 353

13.1.6.2.2 Nikel-Kadmiyum Batarya ................................................. 353

13.1.6.2.3 Ni - MH Batarya ................................................................ 354

13.1.6.3 Lityum Temelli Bataryalar..................................................... 355

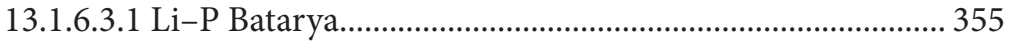

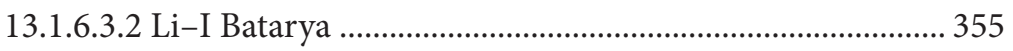

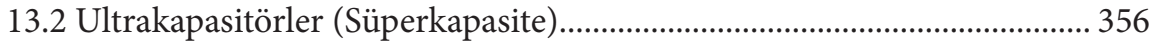

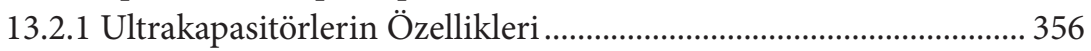

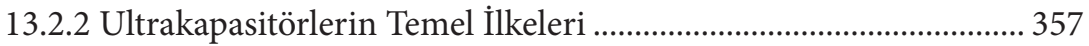

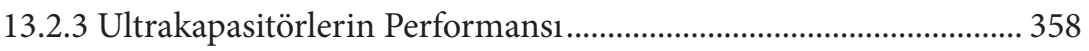

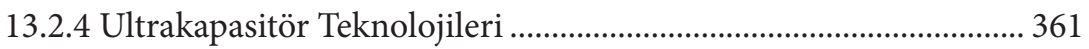

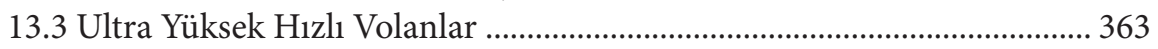

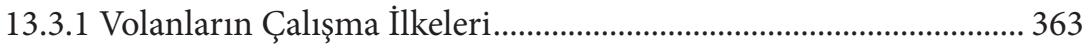

13.3.2 Volan Sistemlerinin Güç Kapasitesi .................................................. 365

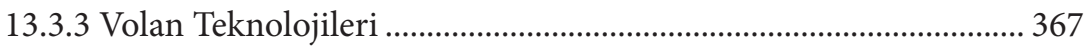

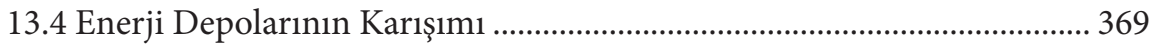

13.4.1 Hibrit (Karma) Enerji Depolama ....................................................... 369

13.4.2 Batarya ve Ultrakapasitör ile Pasif ve

Aktif Hibrit Enerji Depolama ............................................................. 370

13.4.3 Batarya ve Ultrakapasitör Boyut Tasarımı........................................ 371

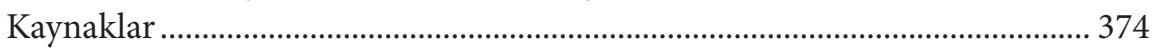

14. Geri Kazanımlı Frenlemenin Temelleri .........................................................377

Çeviri: Dr. Öğr. Üyesi Osman Taha ŞEN

14.1 Şehir İçi Sürüşte Tüketilen Frenleme Enerjisi............................................ 377

14.2 Frenleme Enerjisi ve Taşıt Hızı İlişkisi.......................................................... 378 
14.3 Frenleme Enerjisi ve Frenleme Gücü İlişkisi ......................................... 381

14.4 Frenleme Gücü ve Taşıt Hızı İlişkisi .......................................................... 381

14.5 Frenleme Enerjisi ve Taşıt Yavaşlama İvmesi İlişkisi ................................ 382

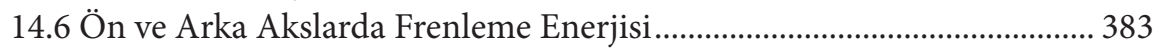

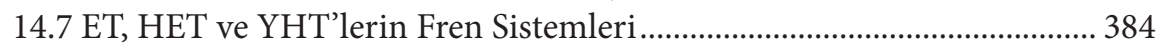

14.7.1 Paralel Hibrit Fren Sistemi ............................................................ 385

14.7.1.1 Elektrikli ve Mekanik Fren Kuvveti Dağılımının

Sabit Oranlı Tasarım ve Kontrol İlkeleri.............................. 386

14.7.1.2 Azami Geri Kazanımlı Fren Enerjisi için Tasarım ve

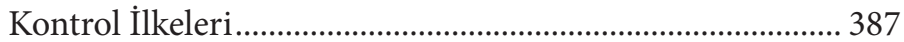

14.7.2 Tamamen Kontrol Edilebilir Hibrit Fren Sistemi .......................... 390

14.7.2.1 En Uygun Frenleme Performansı için Kontrol Yöntemi... 391

14.7.2.2 En Uygun Enerji Geri Kazanımı için Kontrol Yöntemi .... 393

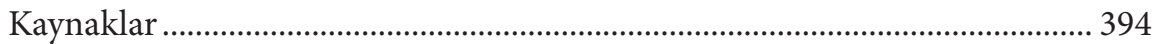

15. Yakıt Pilleri ......................................................................................................397

Çeviri: Prof. Dr. Hamit SOLMAZ

15.1 Yakıt Pillerinin Çalışma İlkesi......................................................................... 397

15.2 Elektrot Gerilimi ve Akım-Gerilim Eğrisi ..............................................400

15.3 Yakıt ve Oksitleyici Madde Tüketimi .......................................................... 403

15.4 Yakıt Hücresi Sistemi Özellikleri ................................................................. 404

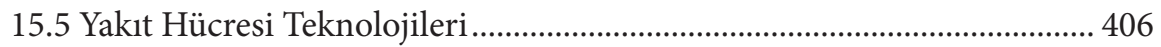

15.5.1 Proton Alışverişine Dayanan Membran Yakıt Hücreleri............... 406

15.5.2 Alkali Yakıt Hücreleri................................................................. 407

15.5.3 Fosforik Asit Yakıt Hücreleri .......................................................... 409

15.5.4 Erimiş Karbonat Yakıt Hücreleri ..................................................... 410

15.5.5 Katı Oksit Yakıt Hücreleri................................................................... 410

15.5.6 Doğrudan Metanol Yakıt Hücreleri.............................................. 411

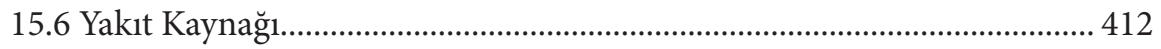

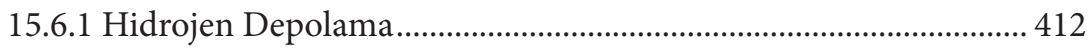

15.6.1.1 Sıkıştırılmış Hidrojen .............................................................. 412

15.6.1.2 Dondurucu (Kriyojenik) Sivı Hidrojen............................... 414

15.6.1.3 Metal Hidritler ........................................................................ 414

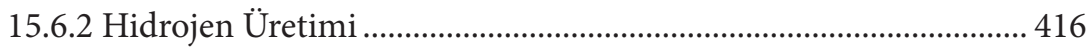

15.6.2.1 Buhar Reforming (Dönüşümü) ........................................... 416

15.6.2.2 Kısmi Oksidasyon Reformasyonu (Dönüşümü)................ 417

15.6.2.3 Ototermal Reformasyon (Dönüşüm) .................................. 417

15.6.3 Hidrojen Taşıyıcı Olarak Amonyak.................................................. 418

15.7 Hidrojensiz Yakıt Pilleri............................................................................ 418

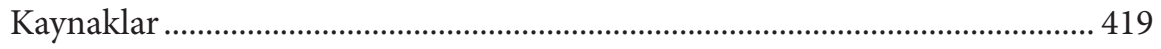


16. Yakıt Pilli Hibrit Elektrikli Tahrik Sistemi Tasarımı 421

Çeviri: Prof. Dr. Hamit SOLMAZ

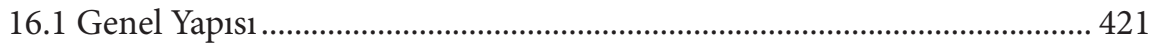

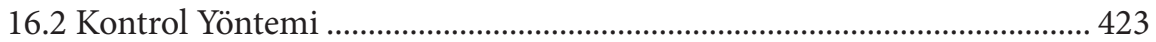

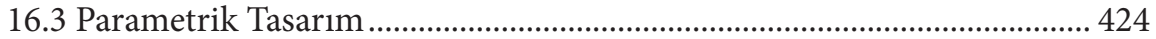

16.3.1 Elektrik Motoru Gücünün Belirlenmesi.......................................... 425

16.3.2 Yakıt Pili Sistem Gücünün Belirlenmesi.......................................... 425

16.3.3 PPS Gücü ve Enerji Kapasitesinin Belirlenmesi ........................... 426

16.3.3.1 PPS’nin Güç Seviyesi.......................................................... 426

16.3.3.2 PPS'nin Enerji Miktarı....................................................... 426

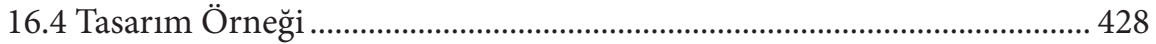

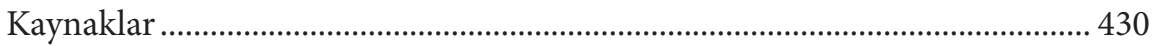

17. Arazi Taşıtları için Seri Hibrit Güiç Aktarma Sistemi Tasarımı ...............431

Çeviri: Dr. Öğr. Üyesi Osman Taha ŞEN

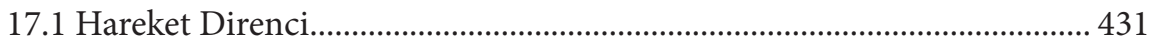

17.1.1 Zemin Sıkıştırma Kaynaklı Hareket Direnci................................. 432

17.1.2 Zemin Yol Düzleme Kaynaklı Hareket Direnci ............................. 434

17.1.3 Güç Aktarma Sisteminin İç Direnci................................................. 435

17.1.4 Arazinin Tahrik Kuvveti ................................................................... 436

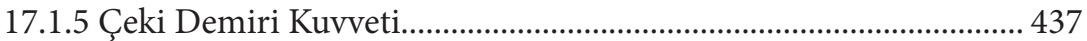

17.2 Paletli Seri Hibrit Taşıt Güç Aktarma Sistemi Mimarisi .......................... 437

17.3 Güç Aktarma Sisteminin Parametre Tasarımı......................................... 438

17.3.1 Tahrik Motoru Güç Tasarımı ...................................................... 439

17.3.1.1 Taşıt Tahrik Gücü ve Taşıt Hızı .......................................... 439

17.3.1.2 Motor Gücü ve Hizlanma Performans1 .............................. 440

17.3.1.3 Motor Gücü ve Tirmanma Performans1............................... 441

17.3.1.4 Paletli Taşıtların Direksiyon Manevrası ............................... 443

17.4 İçten Yanmalı Motor/Generatör Güç Tasarımı........................................... 447

17.5 Enerji Depolama Sisteminin Güç ve Enerji Tasarımı ............................... 449

17.5.1 Tahrik Sistemi için Azami Anlık Güç ............................................ 449

17.5.2 Tahrik için Kullanılmayan Anlık Tepe Gücü ................................. 450

17.5.3 Batarya/Süper-Kapasitörlerin Enerji Tasarımı ............................. 452

17.5.4 Batarya ve Süper-kapasitör Birleşimleri ......................................... 452

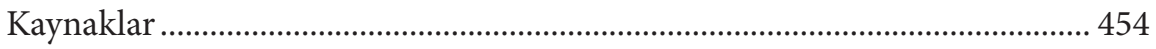

\section{En Uygun Hibritleştirme Oranı ile Tam Boyutlu} IYM Kullanılan HET Tasarımı

Çeviri: Prof. Dr. Can ÇINAR, Prof. Dr. Tolga TOPGÜL, Prof. Dr. Fatih ŞAHİN

18.1. Tam Boyutlu İYM Kullanılan HET’in Tasarım Anlayışı ......................... 457

18.2. En Uygun Hibritleştirme Oranı............................................................. 459 
18.2.1. Otoyol Sürüş Şartlarında Simülasyon 460

18.2.2. Elektrikli Tahrik Gücünün En Uygun Hibritleştirilmesi.............. 463

18.3 10-25 kW Elektrikli Tahrik Paketleri.......................................................... 463

18.3.1 İçten Yanmalı Motor Maksimum Gücüne Duyarlılık.................... 464

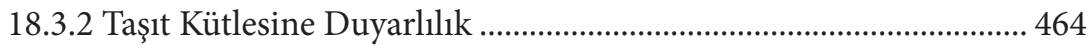

18.3.3 10-25 kW Elektrikli Tahrik Gücü Aralı̆̆ı .................................... 464

18.3.4 Binek Otomobiller için Elektrikli Tahrik Paketi .......................... 468

18.4 Piyasada Bulunan Binek Otomobillerle Karşılaştırma ............................. 468

18.4.1 2011 Model Toyota Corolla ile Karşılaştırma .................................. 469

18.4.2 2011 Model Toyota Prius Hibrit ile Karşılaştırma............................ 470

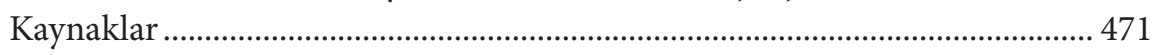

19. Güç Aktarma (Tahrik) Sistemi Optimizasyonu.............................................. 473 Çeviri: Prof. Dr. Okan ÖZGÖNENEL

19.1 Güç Aktarma Sistemi Modelleme Teknikleri .......................................... 473

19.1.1 İleri Yön Taşıt Modeli....................................................................... 474

19.1.2 Geri yön Taşıt Modeli ................................................................................ 474

19.1.3 İleri Yön ve Geri yön Modellerin Karşılaştırılması ........................ 475

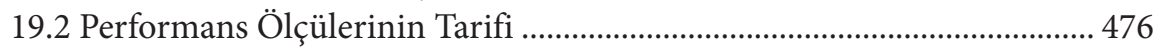

19.2.1 Depodan Tekerleğe Emisyonlar ........................................................ 476

19.2.2 Petrol Kuyusundan Tekerleğe Emisyonlar...................................... 477

19.3 Güç Aktarma Sistemi Simülasyon Yöntemleri......................................... 478

19.4 Modüler Güç Aktarma Sistemi Yapısı........................................................ 480

19.4.1 Önerilen Yazılım Paketinin Çerçevesi ............................................ 481

19.4.2 Modüler Güç Aktarma Sistemi Yapısı............................................... 481

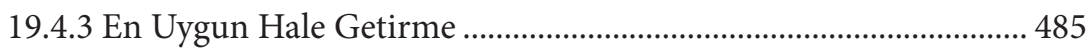

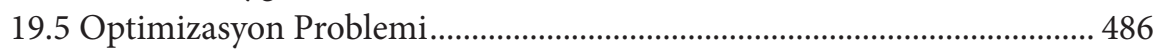

19.5.1 En Uygun Hale Getirmeyi Birden Fazla Güç Aktarma

Sistemi Yapısını Destekleyecek Şekilde Genişletme......................... 486

19.5.2 Çok Amaçlı Optimizasyon ............................................................ 488

19.6 Vaka Sunumları: Güç Aktarma Sistemi Yapısını ve

Eleman Boyutunu En Uygun Hale Getirme .............................................. 488

19.6.1 Vaka Sunumu 1: Depodan Tekerleğe ve Kuyudan Tekerleğe $\mathrm{CO}_{2} 489$

19.6.1.1 Kuyudan Tekerleğe En Düşük $\mathrm{CO}_{2}$ Emisyonları ............... 490

19.6.1.2 Tanktan Tekerleğe En Düşük $\mathrm{CO}_{2}$ Emisyonu..................... 491

19.6.1.3 Çok Amaçlı Optimizasyon....................................................... 492

19.6.2 Vaka Sunumu 2: Kuyudan Tekerleğe Karşı $\mathrm{CO}_{2}$

Güç Aktarma Sistemi Maliyeti.......................................................... 494

Kaynaklar..... 
20. Çok Amaçlı Optimizasyon Yazılımı Paketi için Kılavuz..........................499

Çeviri: Prof. Dr. Okan ÖZGÖNENEL

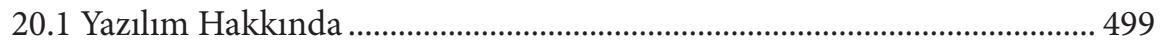

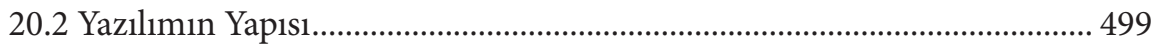

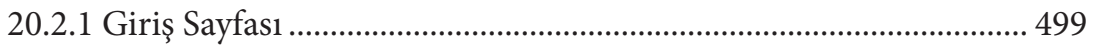

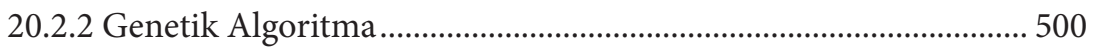

20.2.3 Uygunluk Değerlendirme Algoritması ........................................... 500

20.2.4 Taşıt Davranış Özelliklerinin Simülasyonu ..................................... 500

20.2.5 Mevcut Bileşen Modelleri.................................................................. 500

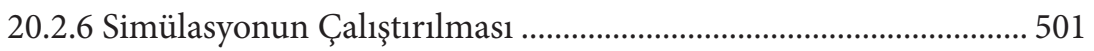

20.2.6.1 Sürüş Çevriminin Tanımı ................................................... 501

20.2.6.2 Maliyet Fonksiyonunun Seçimi.......................................... 501

20.2.6.3 Güç Aktarma Türü Seçimi .................................................... 502

20.2.6.4 Gelişmiş Ayarlar ..................................................................... 503

20.2.7 Simülasyonun Çalıştırılması .............................................................. 503

20.2.8 Sonuçlar ............................................................................................... 505

20.3 Yazılımın Kabiliyetleri ve Sinırlamaları .................................................... 506

Ek: Toyota Prius'a Teknik Bakış ................................................................. 507

Çeviri: Prof Prof. Dr. Mustafa AKTAŞ

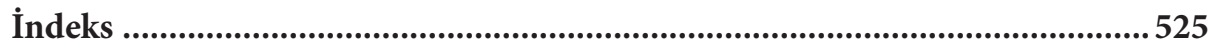




\section{$\ddot{O} n s o ̈ z$}

Elektrikli ve Hibrit Elektrikli taşıtlar günümüzde çok iyi bilinmekte ve uluslararası alanda kabul görmektedir. Ancak, fosil yakıt kullanımına bağlı olarak ortaya çıkan küresel ısınma sorununa giderek artan bilinçlenmeye rağmen, otomobil pazarına tam olarak girememiştir. Bu durum kısmen içten yanma1 motorların düşük maliyeti ve fosil yakıtların bol miktarda bulunmasından kaynaklanmaktadır. Hidrokarbon yakıtların bolluğu onlarca yıldır ve belki de yüzyıllardır değişmemektedir. Dolayısıyla elektrikli ve hibrit elektrikli taşıtlar, ancak otomobil kullanıcısının bugünkü ve gelecekteki ihtiyaçlarına daha iyi ve daha uygun ürünlerin sunulması halinde otomobil pazarına hâkim olabilecektir. Örneğin, düşük maliyetli bir elektrikli taşıt, orta sınıf bir ailenin satın alması ve kullanması için, geleneksel taşıtların çok daha pahalı olduğu, kendi fosil yakıt kaynağı olmayan gelişmekte olan ülkelerde otomotiv pazarına egemen olabilir. Ayrıca, normal boyutlu içten yanmalı motora sahip geleneksel bir taşıt, küçük bir tahrik motoru/generatör ilave edilmesi ile performans, yakıt ekonomisi, emisyon ve maliyet için en uygun hale getirilebilir. Böyle bir taşıt, gelişmiş dünya pazarları için küçük bir maliyet artışı ile geleneksel taşıtlara kıyasla daha üstün bir ürün olabilir.

Kitabımızın üçüncü baskısı, bu alandaki uygun teknolojileri ve tasarım yöntemlerini tanıtarak yukarıdaki amaçlara katkıda bulunmaktadır. Ayrıca bu baskı, kitabın önceki baskılarının okuyucularının önerileri, birçok öğrencinin ve akademisyenlerin önerilerinden yararlanılarak hazırlanmıştır.

İçten yanmalı motor kullanan otomobillerin gelişimi, modern teknolojinin en büyük başarılarından biridir. Ancak, son derece gelişmiş otomotiv endüstrisi ve dünya çapında kullanımda olan otomobil sayısındaki artış, çevre ve hidrokarbon kaynakları için ciddi problemlere sebep olmaktadır. Bozulan hava kalitesi ve küresel ısınma konuları, modern yaşam için ciddi tehditler haline gelmektedir. Daha sıkı emisyon ve yakıt verimliliği standartları, daha temiz, daha güvenli ve daha verimli taşıtların hızlı bir şekilde geliştirilmesini sağlamaktadır. Elektrikli, hibrit elektrikli ve yakıt hücresi ile çalışan güç aktarma sistemi teknolojilerinin, tahmini-öngörülebilir gelecek için en umut verici taşıt çözümleri olduğu artık iyi bilinmektedir.

$\mathrm{Bu}$ meselenin üstesinden gelmek için, $\mathrm{ABD}^{\prime}$ de ve dünya çapında artan sayıda mühendislik bölümleri, lisans ve lisansüstü düzeylerde ileri enerji ve taşıt teknolojileri alanında akademik programlar başlatmıştır. Texas A\&M Üniversitesi'nde makine ve elektrik mühendisliği öğrencileri için ilk yüksek lisans dersine "Gelişmiş Taşıt Teknolojileri-Elektrikli ve Hibrit Elektrikli Taşıtların Tasarım Yöntemi" ismi ile 1998 yılında başladık. Bu ders kapsamında müfredat hazırlarken, teknik makaleler ve raporlar şeklinde zengin bilgi birikimi olmasına rağmen, böyle bir derse katılmak isteyebilecek öğrenciler ve öğretim 
üyeleri için titiz ve kapsamlı bir ders kitabı olmadığını gördük. Ayrıca uygulama mühendislerinin de bu yeni teknolojinin esaslarını tam olarak anlamak için düzenli bir referans kitabına ihtiyaçları bulunmaktadır. Bu kitabın ilk baskısı, bu ihtiyacı karşılama çabamız içindir. Mevcut üçüncü baskı, önceki baskılara ilave yeni konular ve daha derin yaklaşımlar getirmiştir.

Bu kitap, geleneksel içten yanmalı motorlu (İM) taşıtlar, elektrikli taşıtlar (ET), hibrit elektrikli taşıtlar (HET) ve yakıt hücreli taşıtlar (YHT)'nin temelleri, teorik dayanakları ve tasarım yöntemlerini ele almaktadır. Matematiksel titizlikle modern taşıtlar için taşıt performans özellikleri, yapıları, kontrol yöntemleri, tasarım yöntemleri, modelleme ve simülasyon-benzetim çalışması kapsamlı bir şekilde ele alınmıştır. Aktarma elemanları mimarisi analizi, İYM tabanlı aktarma elemanları, ET ve HET yapıları, elektrikli tahrik sistemleri, seri/paralel/hafif hibrit elektrikli aktarma elemanları tasarım yöntemleri, enerji depolama sistemleri, geri kazanımlı frenleme, yakıt hücreleri ve bunların taşıtlardaki ve yakıt hücreli hibrit elektrik aktarma elemanları tasarımı üzerine uygulamaları ele alınmıştır. Kitabın kapsamı, yalnızca tek tek bileşenlerden değil, tüm aktarma elemanları sistemini kapsamaktadır. Tasarım yöntemi matematiksel terimlerle adım adım açıklanmıştır. Ayrıca, her bir aktarma elemanının tasarım yöntemi açıklanırken, tasarım örnekleri benzetim sonuçlarıyla birlikte sunulmuştur.

Daha belirgin olarak, üçüncü baskı, birinci ve ikinci baskılardaki maddelerin birçok düzeltme ve güncellemelerini içermektedir. Dört yeni bölüm ve bir ek (bölüm) dahil edilmiştir. Bunlar, Bölüm 4: Taşıt Güç Aktarma Sistemi; Bölüm 18: En Uygun Hibritleştirme Oranı ile Tam Boyutlu IYM Kullanılan HET Tasarımı; Bölüm 19: Güç Aktarma (Tahrik) Sistemi Optimizasyonu; Bölüm 20: Çok Amaçlı Optimizasyon Yazılımı Paketi için Kılavuz; ve Ek: Toyota Prius'a Teknik Bakış. Ayrıca eski bölümlere bol miktarda yeni bilgiler eklenmiştir. Üçüncü baskıya yapılan tüm bu yeni katkılar, kitabı okuyucu için daha eksiksiz ve kullanışlı yapmaktadır.

Genel olarak bu kitap yirmi bölüm ve bir ek bölüm'den oluşmaktadır. Bölüm 1'de modern ulaşımın sosyal ve çevresel önemi tartışılmaktadır. Bu bölüm, modern ulaşımın gelişmesiyle ilişkili olarak hava kirliliği, küresel ısınma ve petrol kaynaklarının tükenmesi konularını içermektedir. Bu bölümde, gelecekteki taşıt teknolojilerinin yakıt temini üzerindeki etkisi analiz edilmektedir. Sonuçlar, yeni nesil taşıtların geliştirme yöntemlerine yardımcı olmaktadır. Ek olarak, ET, HET ve YHT’nın gelişim tarihi kısaca ele alınmıştır.

Bölüm 2'de taşıt performanlarının temel fikri, güç sistemi özellikleri, aktarım sistemi özellikleri ve taşıt performanslarını açıklamak için kullanılan denklemler verilmektedir. Bu bölümün esas amacı, taşıt güç aktarma elemanları tasarımı için gerekli olan temel bilgileri sağlamaktır. İlk baskıya bir iyileştirme olarak, fren sistemi ve onun tasarımı ve geliştirilmiş malzeme, ET, HET ve $\mathrm{YHT}^{\prime}$ de hibrit fren sistemi tasarımı için daha sağlam bir temel elde etmek amacıyla kuvvetlendirilmiştir. 
Bölüm 3'te, farklı IYMM'lerin temel çalışma özellikleri gösterilmektedir. Ana güç sistemi olarak İYM, geleneksel ve hibrit aktarma elemanı sistemlerinde en önemli alt sistemdir. IYYM özelliklerinin tam olarak anlaşılması, geleneksel taşıtlar gibi hibrit elektrikli taşıtların tasarımında ve kontrolünde gereklidir.

Bölüm 4'te, geleneksel ve hibrit elektrikli taşıt için taşıt aktarma sistemi açıklanmaktadır. Geleneksel ve gelişmiş aktarım sistemlerinin çoğu türleri gösterilmekte ve incelenmektedir.

Bölüm 5'te elektrikli taşıtlar gösterilmektedir. Bu bölüm genel olarak elektrikli tahrik sistemi ve onun enerji depolama biriminin tasarımın, tahrik motoru ve onun aktarım sisteminin tasarımını, taşıt performansının kestirim yöntemi ve sistem benzetim sonuçlarını içermektedir.

Bölüm 6' da ilk olarak hibrit tahrik sisteminin temel kavramı gösterilmiştir. Ardından, hibrit elektrikli taşıtların değişik türleri ele alınmıştır. Bunlar seri hibrit, paralel hibrit, hibritlerin moment bileşimi ve hız bileşimi ve diğer türleri içermektedir. Bu yapıların temel çalışma özellikleri de ayrıca verilmektedir.

Bölüm 7'de çeşitli güç sistemleri ele alınmaktadır. Bunlar DA, AA, kalıcı mıknatıslı fırçasız DA ve anahtarlamalı relüktans motor sürücülerini içermektedir. Tahrik sistemi açısından, onların temel yapıları, çalışma kaideleri, kontrol ve çalışma özellikleri tarif edilmektedir.

Bölüm 8'de, seri hibrit elektrikli tahrik sisteminin tasarım yöntemi gösterilmektedir. Bu bölüm IYYM, enerji depolama, tahrik motoru, aktarma sistemi, kontrol yöntemi ve güç dönüştürücü sistemlerine yönelik tasarıma odaklanmakta ve bir tasarım örneği de verilmektedir. İlk baskıya iyileştirme olarak, çeşitli güç dönüştürücü yapıları ilave edilmiştir.

Bölüm 9'da paralel hibrit elektrikli tahrik sisteminin tasarım yöntemi verilmektedir. Bu bölüm, sürüş şekli ve sürüş periyodu analizi, kontrol yöntemi, ana bileşenlerin tasarımı (IYYM, enerji depolama ve aktarma gibi) ve taşıt performans benzetimi (simülasyonu) içermektedir. İlk baskıya ek olarak, açık ve kapalı kontrol uygulanmış İYM, bulanık mantık kontrolü ve dinamik programlamaya dayalı kontrol optimizasyonu ilave edilmiştir.

Bölüm 10'da seri-paralel hibrit tahrik sisteminin çalışma özellikleri, tasarım yöntemi ve kontrol türleri sunulmaktadır. Bu, ikinci baskıda yeni bir bölüm olarak yer almıştır.

Bölüm 11'de, fişli (plug-in) hibrit taşıtın tasarım ve kontrol ilkeleri açıklanmaktadır. Bu bölüm esas olarak güç aktarım sistemi kontrol yöntemi, enerji depolama tasarımı ve elektrik motoru tasarımı ile ilgili olarak şarj beslemeli hibrit tahrik sistemini ele almaktadır. Bu aynı zamanda yeni bir bölümdür.

Bölüm 12'de, paralel moment bağlantısı ve seri/paralel moment-hız bağlantılı iki temel yapısıyla birlikte hafif hibrit tahrik sistemi tasarım yöntemi açıklanmaktadır. Bu bölüm sistemin analitik incelemesi, kontrol sistemi geliştirme ve sistem benzetimine odaklanmıştır.

Bölüm 13'te, bataryalar, süper kapasitörler ve volanlar dahil olmak üzere farklı enerji depolama teknolojileri ele alınmıştır. Bu çalışma, güç ve enerji ka- 
biliyetlerine odaklanmaktadır. Hibrit enerji depolama kavramı da bu bölümde açıklanmaktadır.

Bölüm 14'te, hibrit fren sistemlerinin tasarım ve kontrol ilkeleri açıklanmıştır. Fren güvenliği ve geri kazanılabilir enerji temel konulardır. Normal sürüş çevrimlerinde, taşıt hızına ve fren gücüne göre uygun frenleme enerjisi özellikleri incelenmektedir. Ön ve arka tekerleklerdeki fren kuvveti dağılımı, güvenli taşıt frenleme performansını sağlamak için ele alınmıştır. Ayrıca bu bölüm, elektriksel geri kazanımlı ve mekaniksel frenler arasında toplam frenleme kuvvetinin dağıtılmasının önemini ele almaktadır. Kontrol yöntemleri de dahil olmak üzere iki gelişmiş hibrit fren sistemi verilmektedir. Bu bölüm, son araştırmamız temel alınarak yeniden yazılmıştır.

Bölüm 15'te, farklı yakıt hücre sistemleri, çalışma ilkelerine ve özelliklerine, çeşitli teknolojilere ve onların yakıtları dikkate alınarak tarif edilmiştir. Özellikle, yakıt hücrelerinin taşıt uygulamaları açıklanmıştır.

Bölüm 16' da yakıt hücreli hibrit tahrik sisteminin düzenli bir tasarımı açıklanmıştır. İlk olarak yakıt hücreli hibrit taşıtlar kavramı ifade edilmiştir. Ardından, çalışma prensipleri ve aktarım kontrol sistemleri incelenmiştir. Son olarak, yakıt hücresi, elektrikli tahrik sistemi ve enerji depolama sistemine odaklanan bir tasarım yöntemi verilmiştir. Bir tasarım örneği ve bu tasarımın performansına ait benzetim (simülasyon) sonuçları verilmiştir.

Bölüm 17'de, bir arazi paletli seri hibrit taşıtın tasarım yöntemi geliştirilmiştir. Bu çalışma, yumuşak zeminlerde hareket direnci hesaplaması, tahrik motor sistemi tasarımı, motor/generatör sistemi tasarımı ve azami güç kaynağı sistem tasarımına odaklanmaktadır.

18, 19 ve 20. bölümleri, üçüncü baskı için yeni bölümlerdir. Bu bölümler, yeni tam boyutlu IYM en uygun hibrit taşıt tasarım kavramını ve taşıt güç sisteminin hibrit hale getirilmesi ve ona bağlı yazılımları açıklamaktadır.

Bu baskıda bir çalışma eki yer almaktadır. Bu ek bölüm, Toyota Prius hibrit sistemine genel bir bakıştır. Amaç, okuyucuya ticari bir hibrit elektrikli tahrik sisteminin mimarisi, çalışma şekilleri, kontrol sistemi ve diğer bileşenlerinin gerçek bir örneğini vermektir.

Bu kitap, ileri düzey taşıtlarda lisansüstü veya üst düzey lisans eğitimi dersi için uygundur. Bu kitaptaki içeriğe destek olmak üzere tasarlanan yazılım (C) 2018 Ganesh Mohan, Francis Assadian, Marcin Stryszowski ve Stefano Longo) kitabın CRC Press web sitesinde (www.crcpress.com/9781498761772) bulunmaktadır. Makine veya elektrik mühendisliği gibi farklı disiplinlerdeki öğrencilerin temel bilgilerine bağlı olarak, ders hocaları kendi derslerine uygun özel içeriği seçme esnekliğine sahiptir. Bu kitap, Texas A\&M Üniversitesi'nde yirmi yıldır lisansüstü düzeyde ders olarak öğretilmektedir. Bu kitabın taslağı, dersimizdeki öğrencilerden gelen yorumlar ve geri bildirimlere dayanarak yıllar boyunca birçok kez revize edilmiştir. Öğrencilerimizin yardımları için onlara minnettarız. 
Bu kitap modern otomotiv sistemleri ile ilgilenen mühendisler, öğrenciler, araştırmacılar ve kamu ve akademide görevli olanlar dahil olmak üzere otomotivle ilgili endüstrilerde çalışan diğer profesyoneller için derinlemesine bir kaynak ve kapsamlı bir referanstır.

Diğer çalışmalara ek olarak, bu kitapta ortaya konulan teknolojilerin ve ilerlemelerin çoğu, yazarlar ve Texas A\&M Universitesi'deki İleri Taşıt Sistemleri Araştırma Programının diğer üyeleri tarafından uzun yıllar süren araştırma ve geliştirmelerin neticesidir. Bu kitaba büyük katkılarda bulunan Texas A\&M'deki Gelişmiş Taşıt Sistemleri Araştırma grubu ve Güç Elektroniği ve Motor Sürücüleri grubunun tüm özverili personeline minnettarız.

Taylor \& Francis Grup çalışanlarının, özellikle de Nora Konopka'nın çabaları ve yardımları için şükranlarımızı sunarız. Son olarak, ailelerimize bu kitabı yazarken uzun emekler boyunca gösterdikleri sabır ve destekleri için teşekkür ederiz.

Mehrdad Ehsani

Yimin Gao

Stefano Longo

Kambiz Ebrahimi

Ocak, 2018

MATLAB® ve Simulink®, MathWorks şirketinin tescilli ticari markasıdır. Ürün bilgileri için lütfen iletişime geçiniz:

The MathWorks, Inc.

3 Apple Hill Drive

Natick, MA 01760-2098 USA

Tel: 508-647-7000

Fax: 508-647-7001

E-mail: info@mathworks.com

Web: www.mathworks.com 



\section{Çeviri Önsözü}

Artan çevre kirliliği, küresel ısınma ve fosil kökenli yakıtların kısıtlı rezervlere sahip olması her geçen gün hibrit ve elektrikli taşıtlara olan ilgiyi arttırmaktadır. Elektrikli taşıtlar kavramı; hibrit elektrikli taşıtlar, bataryalı elektrikli taşıtlar ve yakıt hücreli elektrikli taşıtları kapsamaktadır. Çevirisi yapılan bu kitap söz konusu hibrit ve elektrikli taşıtlara yönelik genel bir perspektif ortaya koymayı hedeflemektedir.

Literatürde, Elektrikli ve Hibrit Elektrikli Taşıtlar alanında önde gelen bu kaynak kitabın Türkçe'ye tercümesi kararımızda, bu alanda yayınlanmış Türkçe kaynak kitap olmaması ve kitabın yazarı Prof Dr Mehrdad EHSANI'nin teşviki bizleri cesaretlendirmiştir.

Kitabın tercümesi Ondokuz Mayıs Üniversitesi, Gazi Üniversitesi, İstanbul Teknik Üniversitesi ve Hakkari Üniversitesi'nden ilgili alanlarda akademik çalışmaları olan uzman 10 Öğretim Üyesi tarafından yapılmıştır. Ayrıca bu çalışmada dil açısından verdiği destekler için Prof. Dr. Mehmet Oruç BİLGIÇ̧'e de teşekkür ediyoruz.

İlk yerli ve elektrikli otomobili üretmeyi hedefleyen TOGG projesi, ülkemizde elektrikli taşıtlara verilen önemi göstermektedir. Bu amaçla kitabın Elektrik-Elektronik, Otomotiv, Makine ve ilgili diğer mühendislik alanlarında eğitim alan önlisans, lisans ve lisansüstü öğrencilere, otomotiv sektöründe çalışan mühendis ve teknik personele, araştırmacılara, akademisyenlere faydalı olacağı ve ülkemiz sanayii ve ekonomisine katkı sağlayacağı kanaatindeyiz. Ayrıca, piyasada alt yapısı son 20 yıldır gelişen Elektrikli Taşıtlara ait faaliyet gösteren firmalara ve mühendislerine de faydalı olacaktır.

Kitapta geçen bazı mesleki kelime ve kelime gruplarının Türkçe'ye kazandırılmasında ilk olması nedeniyle çok dikkat edilmeye çalışılmıştır. Okuyucudan gelecek olan her türlü önerilere de açık olduğumuzu belirtmekte fayda vardır.

Kitabın basımında yabancı yayınevinden (CRC Press Taylor \& Francis Group) telif hakkının alınmasında destek sağlayan “Cengiz Enerji”ye teşekkür ederiz.

Bize bu kitabı basım imkânı veren başta Yasin Dilmen olmak üzere "Akademi Kitabevi" çalışanlarına teşekkür ederiz. Bu değerli eserin öğrencilerimize, akademi camiamıza ve Türk Otomotiv Sanayii'ne hayırlı olmasını temenni ediyoruz. Bu kitabı Türkçe'mize kazandırıyor olmak ta bizim için ayrıca bir mutluluktur. Gayret bizden takdir Allah'tan.

Mustafa AKTAŞ 


\section{Mehrdad Ehsani'nin tercüme kitap hakkında yazısı}

I am delighted to hear that the translation of my book by you is complete.

This book is the result of over thirty years of work on electric and hybrid electric vehicle power trains by this researcher, his graduate students, his research staff and the many visiting scholars that have worked in my lab. Many of these graduate students and visiting scholars came from Turkey. Among these Turkish visiting scholars were Professor Mustafa Aktas and Professor Oruc Bilgich.

I offer my thanks to all of my past graduate students and the visiting scholars whose research work resulted in the advancement of the of EV and HEV technologies. I also hope that the present Turkish edition of the book will help develop the future generation of graduate students and scholars in Turkey and around the world.

Professor Mehrdad Ehsani

October 2021

Mehrdad (Mark) Ehsani, Ph. D., P. E., L.F. IEEE, F. SAE, M. AAAS

Robert M. Kennedy Professor,

Sustainable Energy and Vehicle Engineering Program

Power Electronics \& Motor Drives Laboratory

Department of Electrical \& Computer Engineering

Texas A\&M University

College Station, Texas 77843

Phone: 979-845-7582

Email: ehsani@ece.tamu.edu

Web Address: http:/ / engineering.tamu.edu/electrical/people/mehsani 


\section{Teşekkürler}

Geçmişteki ve şimdiki öğrencilerimizin ve araştırma personelimizin çoğu, son yirmi yılda, bu kitabın meydana gelmesi çalışmalarına katkıda bulundular. Özellikle, Teksas A\&M Üniversitesi'ndeki doktora tezi sayesinde 18. Bölüme katkıda bulunan Lin Lai'nin çalışmasına teşekkür ediyoruz. Texas A\&M Üniversitesi İleri Taşıt Sistemleri Araştırma Programı'ndaki doktora öğrencilerimiz Nima Ersahd, Ahmet Yeksan, Own Golden ve Yiqi Wang'a da yardımları için teşekkür ediyoruz.

Yazarlar, "Güç Aktarma Sistemi Topolojisi ve Bileşen Boyutlandırma için Optimizasyon Teknikleri" ve "Çok Amaçlı Optimizasyon Yazılımı Paketi için Kılavuz" bölümleri ve bu kitapla sağlanan yazılım için, Dr. Ganesh Mohan, Profesör Francis Assadian ve Marcin Staszowski'ye teşekkür etmektedir. Güç aktarım sistemi optimizasyonu tekniklerini ve bu kitapla elde edilebilen MATLAB ${ }^{\circledR}$ tabanlı yazılımı geliştirdiğinde, Dr. Mohan Cranfield Üniversitesi'nde doktora öğrencisiydi. O, şimdi Jaguar Land Rover şirketinde mühendis olarak çalışmaktadır. Esas danışmanı Profesör Assadian, ABD'deki California Davis Üniversitesi'nde profesörlüğe kabulünden önce bu çalışmanın büyük bölümünü yönetti. Staszowski, Cranfield Üniversitesi'nde halen doktora öğrencisidir. Staszowski yukarıda bahsedilen iki bölüm için içerik geliştirme ve yazılım iyileştirmesine katkıda bulunmuştur. Çalışmalarıyla yaptıkları olağanüstü katkısı ve yayınlamamıza izin verdikleri için kendilerine teşekkürü bir borç biliriz. 



\section{Yazarlar}

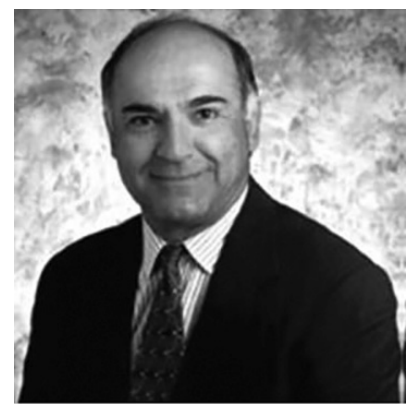

Mehrdad Ehsani, Teksas A\&M Üniversitesi'nde Elektrik Mühendisliği'nin "Robert M. Kennedy" Profesörüdür. 1974'ten 1981'e kadar Teksas Üniversitesi Fusion Araştırma Merkezi'nde araştırma mühendisi ve Argonne Ulusal Laboratuvar (Argonne, Illinois)'ında yardımcı araştırma görevlisi idi. 1981'den beri Texas A\&M Üniversitesi (College Station, Teksas)'nde Elektrik Mühendisliği'nde profesör ve İleri Taşıt Sistemleri Araştırma Programı ve Güç Elektroniği ve Motor Sürücüleri Laboratuvarı'nın yöneticisidir. Anahtarlamalı güç kaynakları, yüksek gerilim mühendisliği, güç elektroniği, motor sürücüleri, ileri taşıt sistemleri ve sürdürülebilir enerji mühendisliği alanlarında 400'den fazla yayının yazarıdır. "Hibrit elektrikli taşıtların teorisine ve tasarımına katkıları" için verilen IEEE Vehicular Society 2001 Avant Garde Ödülü'nü de içeren 100'den fazla uluslararası onur ve takdirlere ilaveten, IEEE-Industry Applications Society tarafından verilen birçok Prize Paper Ödülleri'nin de sahibidir. 2003' de, "güç elektroniği ve sürücülerinin ileri müfredat geliştirme ve öğretilmesine olağanüstü katkıları için" IEEE Lisans Eğitimi Ödülü'ne layık görülmüştür. 2005' de Society of Automotive Engineers (SAE) Üyeliğine seçilmiştir. Güç elektroniği, motor sürücüleri ve ileri taşıt sistemleri üzerine 17 farklı kitabın ortak yazarlarındandır. Kesinleşmiş ve bekleyen 30 'dan fazla $\mathrm{ABD}$ ve $\mathrm{AB}$ patentine sahiptir. Şu anki araştırma çalışmaları güç elektroniği, motor sürücüleri, hibrit taşıtlar ve bunların kontrol sistemleri ve sürdürülebilir enerji mühendisliği üzerinedir.

Dr. Ehsani, IEEE Güç Elektroniği Topluluğu (PELS:Power Electronics Society) AdCom üyesi, PELS Eğitim İşleri Heyeti başkanı, IEEE-IAS Endüstriyel Güç Dönüştürücüleri Heyeti başkanı ve IEEE Myron Zucker Öğrenci-Hoca Ödülü programı başkanıdır. 1990' daki IEEE Power and Propulsion Konferansı'nın genel başkanıdır. IEEE Power and Propulsion Conference'nın kurucusu, IEEE VTS Vehicle Power and Propulsion'ın kurucu başkanı ve Convergence Fellowship Heyetleri başkanı'dır. 2002' de VTS yönetim kuruluna seçildi. Ayrıca birçok teknik dergilerin yayın kurulunda görev yapmaktadır ve IEEE Transactions on Industrial Electronics ve EEE Transactions on Vehicular Technology'nin editör yardımcılığını yapmıştır. IEEE'nin yaşam boyu onur üyesi, IEEE Industrial Electronics Society ve Vehicular Technology Society'nin seçkin konuşmacisı ve IEEE Industry Applications Society ve Power Engineering Society'nin seçkin öğretim üyesidir. Kendisi ayrıca Teksas eyaletinde kayıtlı profesyonel bir mühendistir. 


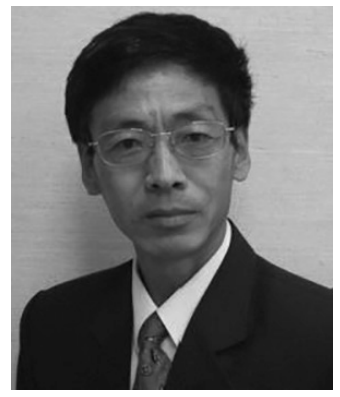

Yimin Gao, tümü Jilin Teknoloji Üniversitesi (Changchun, Jilin, Çin)'nden olmak üzere sırasıyla 1982, 1986 ve 1991 yıllarında makine mühendisliğinde (otomotiv sistemlerinin geliştirilmesi, tasarımı ve üretimi alanında) lisans, yüksek lisans ve doktora derecelerini aldı. 1982'den 1983'e kadar Dongfeng Motor Şirketi (Shiyan, Hubei, Çin)'nde taşıt tasarım mühendisi olarak çalıştı. 5 tonluk bir kamyonun (EQ144) yerleşim tasarımını bitirdi ve aracın prototip oluşturma ve testinde görev aldı. 1983'ten 1986'ya kadar Jilin Teknoloji Üniversitesi (Changchun, Jilin, Çin) Otomotiv Mühendisliği Bölümü'nde lisansüstü öğrenci idi. Buradaki çalışma alanı, motor ve şanzımanın en uygun eşleşmesi ile taşıt yakıt ekonomisinin iyileştirilmesidir.

1987'den 1992'ye kadar Jilin Teknoloji Üniversitesi (Changchun, Jilin, Çin) Otomotiv Mühendisliği Bölümü'nde doktora eğitimini aldı. Bu süre zarfında, tekerlekli taşıtlar için hareketin güç olduğu arazi şartlarında imkân dahilinde çalışabilen ayaklı taşıtların araştırma ve geliştirmesi üzerine çalıştı. 1991'den 1995'e kadar, Jilin Teknoloji Üniversitesi Otomotiv Mühendisliği Bölümü'nde doçent ve otomotiv tasarım mühendisiydi. Bu dönemde, lisans öğrencilerine birçok kez otomotiv teorisi ve tasarımı dersi ve yüksek lisans öğrencilerine iki kez otomotiv uygulama tekniği dersi verdi. Bu arada, taşıt performansı, şasi ve parçaların incelemesini de gerçekleştirdi ve ayrıca şasi tasarımı, güç aktarma sistemi tasarımı, süspansiyon tasarımı, direksiyon sistemi tasarımı ve fren tasarımı dahil olmak üzere otomotiv tasarımını gerçekleştirdi.

1995 yılında Texas A\&M Üniversitesi'nde Advanced Vehicle Systems Research Programına araştırma görevlisi olarak katıldı. Halen, bu programda elektrikli ve hibrit elektrikli taşıtların araştırma ve geliştirilmesi üzerine çalışmaktadır. Araştırma alanları esas olarak elektrikli ve hibrit elektrikli güç aktarımının temelleri, mimarisi, kontrolü, modellemesi, tasarımı ve esas bileşenleridir. Gao SAE üyesidir.

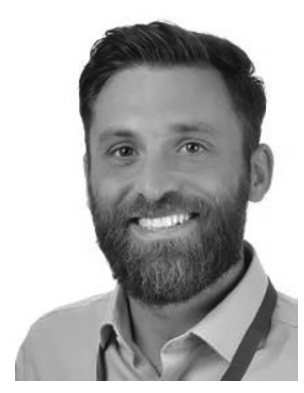

Stefano Longo, elektrik ve elektronik mühendisliği'nden mezun olduktan sonra, 2007 yılında Sheffield Üniversitesi (İngiltere)'nde kontrol sistemlerinde yüksek lisans ve 2010 yllında Bristol Üniversitesi (İngiltere)'nde yine kontrol sistemleri alanındaki doktora derecesini elde etti. Doktora tezi, kontrol mühendisliği alanındaki önemli başarıları nedeniyle Mühendislik ve Teknoloji Enstitüsü (IET:Institution of Engineering and Technology) Kontrol ve Otomasyon Ödülü'ne layık görüldü. 2010'da Imperial College Londra (İngiltere)'da Elektrik ve Elektronik Mühendisliği Bölümü bünyesindeki Kontrol ve Güç Grubu'na araştırma görevlisi olarak atandı ve burada kontrol sistemleri tasarımı ve donanım uygulaması ortak alanlarında 
çalıştı. 2012' de Cranfield Üniversitesi (İngiltere) Otomotiv Mühendisliği Bölümü'nde (şimdiki adı İleri Taşıt Mühendisliği Merkezi) taşıt elektrik ve elektronik sistemleri alanında hoca (doktor öğretim üyesi) olarak atandı. 2012'den 2016'ya kadar Imperial College Londra'da fahri araştırma görevliliği yaptı. 2017 'de, Dr. Longo, otomotiv kontrol ve optimizasyon alanında kıdemli hoca (doçent) pozisyonuna terfi etti ve 2014'ten beri otomotiv mekatronik alanında yüksek lisans için ders yöneticisi olarak görev yapmaktadır.

Dr. Longo, 70'in üzerinde hakemli araştırma makalesi ve bir kitap, Optimal and Robust Scheduling for Networked Control Systems (CRC Press, 2017) yayınlamıştır. Otomotiv mekatroniği, optimizasyon ve kontrol alanlarında çeşitli lisansüstü dersler vermekte, doktora öğrenci danışmanlığı ve akademik araştırma ve danışmanlık yürütmektedir.

Dr. Longo, IEEE'nin kıdemli üyesi, Elsevier dergisi Mechatronics'in yardımcı editörü, birçok IEEE ve IFAC dergisinin teknik editörü ve hakemi, yeminli mühendis ve IET Control \& Automation Network'ün seçilen yönetici üyesi, Mechatronic Systems and Automotive Control'de IFAC teknik heyeti üyesi ve Yüksek Öğretim Akademisi üyesidir.

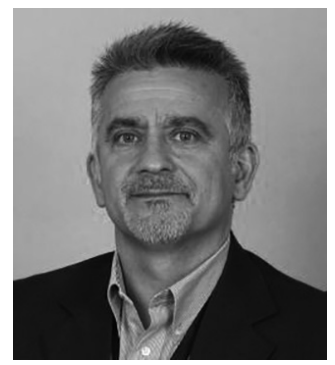

Kambiz M. Ebrahimi, makine mühendisliği lisans derecesini Plymouth Polytechnic (İngiltere)'ten, yüksek lisans derecesini UWIST'den sistem mühendisliği'nde (Galler Üniversitesi) ve doktorasını Cardiff Üniversitesi (İngiltere)'nden dinamik ve matematiksel modelleme alanında almıştır.

Şu anda, Loughborough Üniversitesi (İngiltere) Havacılık ve Otomotiv Mühendisliği Bölümü'nde ileri tahrik sistemleri profesörüdür. Loughborough'ya girmeden önce, Galler Üniversitesi'nde bir AB projesinde modele dayalı durum izleme üzerine ve Bradford Üniversitesi'nde dağıtık-toplu modelleme ve asgari güç ile kontrol yöntemleri üzerinde araştırma görevlisi olarak çalıştı. Daha sonra, Bradford Üniversitesi (İngiltere) makine mühendisliği'nde okutman, doçent ve profesör oldu.

Başlıca araştırma alanları sistemler ve kontrol teorisi; çok değişkenli ve büyük ölçekli sistemler; mekatronik sistemlerin modellenmesi ve özellikleri; hibrit güç aktarma sistemlerinin enerji yönetimi ve kontrolü; sistem izleme, arıza teşhisi ve Turbomakine kanat ucu zamanlamasi; hibrit, elektrikli ve L-sınıfı taşıtlardır. Ulusal ve uluslararası dergi ve konferanslarda 100'den fazla makalenin yazarı veya ortak yazarıdır.

Dr. Ebrahimi, yetkili bir makine mühendisi ve ASME ve SAE üyesidir ve 2012'den beri Powertrain Modelling and Control Conference'nın başkanı ve düzenleyicisi olarak görev yapmaktadır; 2012'den beri International Journal of Powertrains'in yayın kurulu üyesidir ve 2009 'da the Challenges in Powertrain Testing toplantılarının düzenleyicisidir. Aynı zamanda, Application of Multi-Va- 
riable System Techniques (1998, Professional Engineering Publishing) kitabının yardımcı editörü ve Multi-Body Dynamics (2000, Professional Engineering Publishing) kitabının yardımcı editörlüğüne ilaveten Proceedings of the Institution of Mechanical Engineers, Part K: Journal of Multi-body Dynamics'in de yayın kurulu üyesidir.

AVL, Ford Motor Şirketi, Cummins Turbocharger Teknolojileri, Jaguar ve Land Rover gibi bağlantıları aracılığıyla endüstri ile araştırma iş birliğinde aktif olarak yer almaktadır. 


\section{Tercüme Kurulu}

\section{Prof. Dr. Mustafa AKTAŞ}

Ondokuz Mayıs Üniversitesi, Mühendislik Fakültesi, Elektrik Elektronik Mühendisliği

ORCID iD: 0000-0002-2608-1000

\section{Prof. Dr. Necmi ALTIN}

Gazi Üniversitesi, Teknoloji Fakültesi, Elektrik Elektronik Mühendisliği ORCID iD: 0000-0003-3294-9782

Prof. Dr. Ahmet Faruk BAKAN Yıldız Teknik Üniversitesi, Elektrik Elektronik Fakültesi, Elektrik Mühendisliği

ORCID iD: 0000-0002-0399-0359

\section{Prof. Dr. Can ÇINAR}

Gazi Üniversitesi, Teknoloji Fakültesi, Otomotiv Mühendisliği

ORCID iD: 0000-0001-6944-8864

\section{Doç. Dr. Mesut DÜZGÜN}

Gazi Üniversitesi, Teknoloji Fakültesi, Otomotiv Mühendisliği

ORCID iD: 0000-0003-0582-4183

\section{Dr. Öğr. Üyesi Tayfun GÜNDOĞDU}

Hakkâri Üniversitesi, Mühendislik

Fakültesi, Elektrik Elektronik

Mühendisliği

ORCID iD: 0000-0002-7150-1860
Prof. Dr. Okan ÖZGÖNENEL

Ondokuz Mayıs Üniversitesi, Mühendislik Fakültesi, Elektrik Elektronik Mühendisliği

ORCID iD: 0000-0001-9995-1460

\section{Prof. Dr. Hamit SOLMAZ}

Gazi Üniversitesi, Teknoloji Fakültesi, Otomotiv Mühendisliği

ORCID iD: 0000-0003-0689-6824

\section{Doç. Dr. Fatih ŞAHİN}

Gazi Üniversitesi, Teknoloji Fakültesi, Otomotiv Mühendisliği ORCID iD: 0000-0002-4423-6619

Dr. Öğr. Üyesi Osman Taha ŞEN İstanbul Teknik Üniversitesi, Makina Fakültesi, Makina Mühendisliği ORCID iD: 0000-0002-8604-3962

Doç. Dr. Tolga TOPGÜL

Gazi Üniversitesi, Teknoloji Fakültesi, Otomotiv Mühendisliği

ORCID iD: 0000-0003-1347-9594 